\title{
Staphylococcus epidermidis biofilms: functional molecules; relation to virulence and the host immune response
}

\author{
Fatima R. Abdul ${ }^{\mathrm{a}}$, Ihsan A. Raheem ${ }^{\mathrm{b}}$, Raghad A. Abdulrazaq ${ }^{\mathrm{a}}$, Hanan T. Subhi ${ }^{\mathrm{c}, *}$ \\ a Department of Biology, College of Science, Mustansiriyah University, Baghdad, Iraq (mht1695@uomustansiriyah.edu.iq) \\ (raghadlatif65@uomustansiriyah.edu.iq) \\ ${ }^{b}$ Medical Laboratory Technology Department, Gilgamesh University-Baghdad, Iraq (qetasyshah@gmail.com) \\ ${ }^{c}$ Department of Biology, Faculty of health and science, Koya University, Kurdistan Region, Iraq \\ (hanan.baker@koyauniversity.org) \\ *Correspondence: hanan.baker@koyauniversity.org
}

\begin{abstract}
Staphylococcus epidermidis is the most significant nosocomial pathogen related to people with vulnerable frameworks such as malignant growth patients, neonates, and foreign body embedded materials such as heart valves. A few virulence factors in $S$. epidermidis can cause host damage in comparison to Staphylococcus aureus. In spite of that, the key roles of $S$. epidermidis virulency rely on biofilm formation, bacterial biofilm is essential for the pathogenesis by encouraging microorganisms to consist shape networks of assurance rather than free planktonic cells, hence resistance to antibacterial agents, and medically uninsured problems by colonizing medical indwelling, making the disease long span, and difficult to treat. The National Institute of Health (NIH) reported 65-80\% of bacterial illnesses are biofilm formed, thus making numerous passing wellbeing additional costs. Therefore, the biofilms establishing on the susceptible hosts' tissues demonstrate; preventing antibiotics efficient treatment, protecting against host defense mechanisms, and announce the bacteria virulence determinants manifesting.
\end{abstract}

Keywords: Staphylococcus epidermidis, Biofilm, Virulence, Immune defense

Received: June $5^{\text {th }}, 2021 /$ Accepted: Sept $5^{\text {th }}, 2021 /$ Online: Sept. $27^{\text {th }}, 2021$.

\section{INTRODUCTION}

Staphylococci are gram-positive bacteria (cocci) nonmotile, non-spore-forming, facultative anaerobic which routinely remain gathered in grape-like gatherings; The establishment of biofilm in creatures, individuals, and on therapeutic contraptions are the fundamental factor of Staphylococci related severe infections (Hago, 2018). In addition to the biofilm being one of the major destructiveness elements of microorganisms, most nosocomial contamination is Staphylococci, thus the biofilm capacity to develop in medical strains is more significant and the diseases of staphylococcus offer protection from a wide range of antibiotics (Fisher et al., 2017). S. epidermidis is an adaptable agent, most nosocomial and commensal pathogen by the opportunistic part relationship, perceived as a significant reason of disease in the world and largely hospital-acquired, as well a capacity to arrangement strong biofilms on attachment surfaces, in this manner giving approach to infections of connected catheter and valve of heart related infections as equipment of medicine can develop handily by dirty skin of visitors and hospital workers (Costa et al., 2018). Staphylococci groups are divided into two collections depending on the capability to produce coagulase, the enzyme that coagulation of blood plasma: positive staphylococci coagulase and negative staphylococci coagulase, $S$. aureus collected through $S$. epidermidis have vigorous another as causative infection of medical places (Bastos et al., 2010). S. epidermidis is the main microbe among the negative staphylococci coagulase. It's an individual of human skin microbiota and misty mucosa, nevertheless it might perform, for example, the agent of disease which might have an important occurrence particularly in patients with immune deficiency (Fontana and Favaro 2018; Foster et al., 2014). 


\section{II.VIRULENCE FACTORS}

The virulence mechanisms of $S$. epidermidis are remain unclear due to the high genetic variation which may be a new marker and drug target against $S$. epidermidis invasiveness (Wang et al.,2020). Several virulence factors have been defined in this review; we mostly focused on biofilm formation as a significant virulence factor (Cheung et al., 2010). Moreover, the invasion of human immune defense by the bacteria becomes a non-harmful function as soon as the life of bacteria as a commensal on, such as the human skin (Lood et al., 2015), and this ability is still not completely understood; consequently, S. epidermidis is occasionally referred to as "the accidental pathogen" (Bottagisio et al., 2020).

S. epidermidis dissimilar many bacteria that produce toxins, the amphipathic peptide, phenol-soluble modulins (PSMs) found in S. epidermidis, and held several roles; interacts with biofilm formation, regulate by quorum sensing, and causes sepsis by influencing the human innate immune system response (Henderson et al., 1996). PSMs consist of three parts, PSM $\alpha$, PSM $\beta$, and PSM $\gamma$ (Mehlin et al., 1999). S. epidermidis delta-toxin is identical to PSM $\gamma$ and similar to $\mathrm{PSM} \alpha$, as antimicrobial activity, cytolytic capacity, and support of provocative (Oliveira et al., 2018; Tam and Torres 2019), under brutal guideline (Table1). The delta-poison (hld) quality is under the control of the accessory gene regulator (agr) quorum sensing system and translated by RNAIII deltapoison. Only one quorum sensing system is known in $S$. epidermidis, which also encodes virulence factors. Furthermore, delta-poison associated with methicillinresistant strains, the conflict of methicillin recognized through the existence of the mecA gene, which often has a low affinity for $\beta$-lactam antibiotics (PBP2A) and encode a penicillin-binding protein (Pruneau, 2008). Delta-poison helps out human coetaneous insusceptible guards (Surewaard, 2013).

Hemagglutinin is a glycoprotein, causes the red blood cells (RBCs) to coagulate, consisting of several types that act at different temperatures, S. epidermidis hemagglutinin is not influenced by the $\mathrm{pH}$, temperature, concentration of proteases, serum proteins, cleanser detergent, or subinhibitory anti-infection agents. Their importance in $S$. epidermidis pathogenesis plays a direct role in adherence to polymers, the first step in biofilm formation along with that is biomaterial-associated infections (Essa et al., 2015). Furthermore, hemagglutination has been eliminated via oxidation and absorption with glycosidases and significantly repressed by beta-lactose with the simple saccharide components in a focus dependent on design. Examination of the cells that do not hemagglutinate appears supernatant compounds containing next to zero protein and minor amounts of reducing sugars, ketose, pentose, hexosamine, phosphate, and uronic corrosive. Henceforth, S. epidermidis hemagglutinin contains different types of polysaccharides to adhesins (Bermudes, 2019).
Table 1. Extracellular enzymes and exotoxins of S.epidermidis (Otto, 2009).

\begin{tabular}{|c|c|c|}
\hline Enzyme name & Category & Biological activity \\
\hline Staphylococcal cysteine B & $\begin{array}{l}\text { Proteases of } \\
\text { cysteine }\end{array}$ & Damage of tissue \\
\hline $\begin{array}{l}\text { Cysteine protease of } \\
\text { extracellular }\end{array}$ & $\begin{array}{l}\text { Proteases of } \\
\text { cysteine }\end{array}$ & Damage of tissue \\
\hline $\begin{array}{l}\text { Efflux pump of } \\
\text { Staphylococcal }\end{array}$ & $\begin{array}{l}\text { Elastase or } \\
\text { metallo- } \\
\text { protease }\end{array}$ & $\begin{array}{l}\text { Tissue damage, AMP } \\
\text { resistance and Lipase } \\
\text { maturation. }\end{array}$ \\
\hline $\begin{array}{l}\text { S. epidermidis of } \\
\text { Glutamyl endopeptidase, }\end{array}$ & $\begin{array}{l}\text { Glutamic } \\
\text { endo-peptidase }\end{array}$ & Destruction of fibrinogen \\
\hline $\begin{array}{l}\text { Serine enzyme of } \\
\text { Staphylococcal }\end{array}$ & $\begin{array}{l}\text { Protease of } \\
\text { serine }\end{array}$ & $\begin{array}{l}\text { Complement factor C5 and } \\
\text { fibrinogen degradation }\end{array}$ \\
\hline Glycerol ester hydrolase & $\begin{array}{l}\text { Lipases } \\
\text { enzymes }\end{array}$ & $\begin{array}{l}\text { Determination fatty acid, } \\
\text { Discharges }\end{array}$ \\
\hline $\begin{array}{l}\text { Altering enzymes of Fatty } \\
\text { acid }\end{array}$ & Un known & $\begin{array}{l}\text { Bactericidal fatty acids } \\
\text { detoxification }\end{array}$ \\
\hline Urease enzymes & $\begin{array}{l}\text { Urease } \\
\text { enzymes }\end{array}$ & $\begin{array}{l}\text { Bacterial invasiveness, } \\
\text { ureolysis, and } \mathrm{pH} \text { changes. }\end{array}$ \\
\hline $\begin{array}{l}\text { Phenol-soluble modulins, } \\
\text { for instance, Delta }(\delta) \\
\text { toxin }\end{array}$ & $\begin{array}{l}\text { Toxins of } \\
\text { tissue- } \\
\text { damaging }\end{array}$ & $\begin{array}{l}\text { Cytolysins of } \\
\text { proinflammatory, for } \\
\text { example, affecting } \\
\text { necrotizing enterocolitis }\end{array}$ \\
\hline $\begin{array}{l}\text { Teichoic acids D- } \\
\text { alanylation }\end{array}$ & $\begin{array}{l}\text { Proteins related } \\
\text {-AMP }\end{array}$ & teichoic acid D-alanylation \\
\hline $\begin{array}{l}\text { Multiple peptide resistance } \\
\text { factor protein }\end{array}$ & $\begin{array}{l}\text { Proteins related } \\
\text {-AMP }\end{array}$ & Phospholipids Lysylation \\
\hline Vancomycin resistance & $\begin{array}{l}\text { Proteins related } \\
\text {-AMP }\end{array}$ & AMP exporters \\
\hline $\begin{array}{l}\text { Antimicrobial peptide- } \\
\text { sensing system (APS) }\end{array}$ & $\begin{array}{l}\text { Proteins related } \\
\text {-AMP }\end{array}$ & $\begin{array}{l}\text { controls AMP, resistance } \\
\text { mechanisms, and AMPs } \\
\text { of senses. }\end{array}$ \\
\hline Staphylo ferrins & $\begin{array}{l}\text { Importer of } \\
\text { Iron }\end{array}$ & $\begin{array}{l}\text { Acquisition of Bacterial } \\
\text { iron }\end{array}$ \\
\hline Siderophores & $\begin{array}{l}\text { Importer of } \\
\text { Iron }\end{array}$ & $\begin{array}{l}\text { Acquisition of Bacterial } \\
\text { iron }\end{array}$ \\
\hline $\begin{array}{l}\text { Iron transporter } \mathrm{ABC} \text { of } \\
\text { Staphylococcal }\end{array}$ & $\begin{array}{l}\text { Importer of } \\
\text { Iron }\end{array}$ & $\begin{array}{l}\text { Acquisition of Bacterial } \\
\text { iron }\end{array}$ \\
\hline
\end{tabular}

On the external surface of the bacterium the proteins are tied decisively to buildups of sugar on the erythrocyte surface and different cells of eukaryotic (Goneau, 2014), this protein revealed to bind fibronectin, and mediate adherence to the surface protein of sheep erythrocytes (Miyoshi et al., 2006). Often, a wide variety of erythrocytes can agglutinate because nonspecific and carbohydrate nature of $S$. epidermidis hemagglutinin. While hemagglutination can be inhibited by purified polysaccharide intercellular adhesin (PIA), a specific receptor of hemagglutinin that might be interacting with PIA on the erythrocyte surface (Duffus et al., 2017), PIA is essential for a specific action of $S$. epidermidis 43 
hemagglutinin, for example, icaADBC operon contained glycosyltransferase which is a single homologous gene and without any synthetic genes associated with the biosynthesis of sugar precursor (Somerville et al., 2009), The disruption of icaADBC operon could result in polysaccharide synthesis impaired from PIA. In addition, erythrocyte hemagglutination is a characteristic of $S$. epidermidis that correlates with the formation of biofilms and is necessary for biomaterial-associated infections pathogenesis which is explained by S. epidermidis (Ong et al., 2019).

Poly- $\gamma$-glutamic acid (PGA) and Polysaccharide intercellular adhesion (PIA) play an important role by protecting the bacteria against innate host defense; phagocytosis of neutrophils, antimicrobials peptides and is essential for survival, such as promoting growth during high salt concentrations as commensal on the skin and increased osmotolerance of biofilms in infectious agents (Sabaté Brescó et al., 2017). S. epidermidis exopolymers with biofilm formation have analogous functions such as poly- $\gamma$-glutamic acid defense against immunoglobulins and deposition of complement (Bocian et al., 2020). The PIA produced by $S$. epidermidis adhesins is measured to be the chief efficient component interceding intercellular linkage in biofilms by adhesion of cell-to-cell on non-living surfaces, furthermore act as the main virulence factor in experimental biomaterialassociated infections (Kucinskas, 2017).

PNAG plays a role in the pathogenesis of S. epidermidis (Otto, 2014), the immunological homology between the staphylococcal PNAG and poly-glucosamine on gramnegative pathogens could protect against numerous major human pathogens because PNAG appears to be of great importance through putting vaccine against PNAG. The proteins encoded by the icaADCB locus are used to synthesize PNAG (Zecconi and Scali, 2013), PNAG has several functions: it's responsible for biofilm maturation and cell actions such as intercellular adhesion, which encourages cell-to-cell collection (Otto, 2018). S. epidermidis biofilm polysaccharide intercellular adhesin deacetylase (IcaB) encouraging PNAG deacetylation which is essential for biofilm formation and connotation by the surface of bacterial cells (Otto, 2009) (fig.1). Poly-N-Acetyl-Glucosamine plays a critical role in the protection of planktonic $S$. epidermidis from antibodies (Rao, 2020). Biofilms of S. epidermidis widen to about $100 \mu \mathrm{m}$, although the famous rise in PNAG production is associated with biofilm development, the antibody continues to transmit during the biofilm (Gonçalves, 2016)

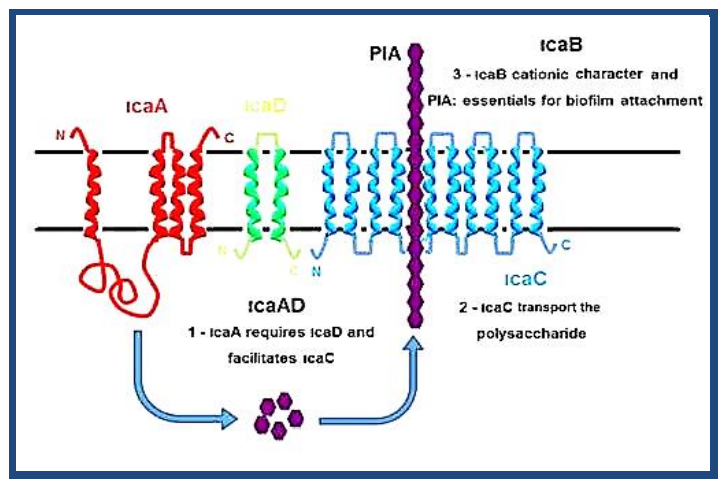

Figure 1. Outlining the activity of proteins icaADBC on biofilm formation process (A) and mechanisms of agr quorum sensing (B). (A) Proteins involved in exopolysaccharide synthesis of PIA are complex genomic icaADBC. Proteins icaA, icaC and icaD are transmembrane proteins and protein icaAB is located in the extracellular matrix. The first step in the synthesis of PIA is icaAD association will facilitate the export of PIA via membrane through association and activation of icaAC. Once in the extracellular matrix, PIA protein icaAB removes some $\mathrm{N}$-acetyl groups, providing essential cationic character for attaching to surfaces (SilvaSantana et al., 2015).

This possible resistance strategy to opsonic destruction is unlikely to explain the diminished cell murdering. Moderately, the expansion of PNAG inside the biofilm appeared to defeat the additional counteracting agent and equipped to repress the slaughter of planktonic cells when the network of biofilm blended with neutralizer which was used as a measure of phagocytosis (Smith, 2016) (Fig.2). PNAG particles have been utilized as an objective for the discovery of immunizations based on antibodies targeting staphylococcal PNAG particles, the development of antibodies based on PNAG may be utilized against different specialists of irresistible sicknesses (Sause et al., 2016), which is the furthermost significant harmful property found in biofilm formation and in S. epidermidis; thus, the immune system of the host contributes to the persistence of biofilm infections and protection the bacteria from antimicrobial agents (Gomes et al., 2014).

\section{A. Biofilm}

Typically, assessment of the proposed destructiveness factors reveals that $S$. epidermidis has developed different frameworks to protect itself against elements of the intrinsic insusceptible framework, including antimicrobial peptides and phagocytosis, rather than those elements that help with intervening obtrusive contaminations (Jyoti et al., 2020). Otto in 2009 has as of late distributed a few fantastic surveys zeroing in the science of $S$. epidermidis, as of late depicted the phenol-solvent modulins (PSMs) consist of three-part antimicrobial peptide framework and different variables help the intervention protection from the inborn resistant framework (Singh et al., 2017).

surface component recognizing adhesive matrix molecule (Otto, 2009). 


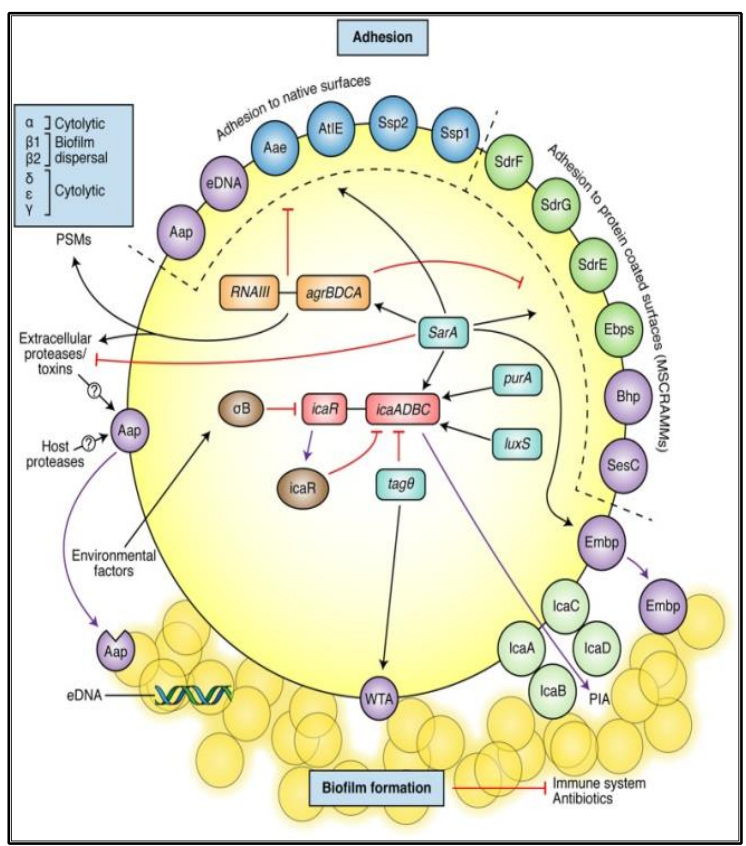

Figure 2. S.epidermidis main mechanisms of biofilm formation and adhesion molecules (Sabaté Brescó et al., 2017),).

Table 2. Major EPSs Components and Their Function in Biofilms of Bacteria (Flemming et al., 2016) Functions of EPS Components in the Biofilms Context.

\begin{tabular}{|c|c|}
\hline Polysaccharides & $\begin{array}{l}\text { Adhesion, aggregation of bacterial cells, cohesion } \\
\text { of biofilms, protective barrier, retention of water } \\
\text { (by hydrophilic polysaccharide), sorption of } \\
\text { organic and inorganic compounds sinks for excess } \\
\text { energy. }\end{array}$ \\
\hline Proteins & $\begin{array}{l}\text { Enzymatic activity, electron donor or acceptor, } \\
\text { adhesion, aggregation of bacterial cells, cohesion } \\
\text { of biofilms, protective barrier, sorption of organic } \\
\text { and inorganic compounds sinks for excess energy, } \\
\text { export of cell component. }\end{array}$ \\
\hline DNA & $\begin{array}{l}\text { exchange of genetic information, adhesion, } \\
\text { aggregation of bacterial cells, cohesion of } \\
\text { biofilms. }\end{array}$ \\
\hline Divalent ions & $\begin{array}{l}\text { Mechanical stability, regulation of bap, regulation } \\
\text { of EPS production. }\end{array}$ \\
\hline $\begin{array}{l}\text { Surfactants and } \\
\text { lipids }\end{array}$ & $\begin{array}{l}\text { Bacterial attachment and detachment, } \\
\text { hydrophobicity. }\end{array}$ \\
\hline Water & $\begin{array}{l}\text { Provides hydrated environment, medium for } \\
\text { movements for nutrients. }\end{array}$ \\
\hline
\end{tabular}

By the specific instrument needed to frame utilitarian, developing of staphylococcal biofilms looked obscure. Be that as it may, it has been traditionally seen as a four-venture measure: adherence, aggregation, development, and separation (Josse et al., 2019). A developed S. epidermidis biofilm comprises an assortment of cement atoms, including polysaccharide intercellular adhesin (PIA), proteinaceous elements (Bhp, Aap, and Embp), teichoic acids, and extracellular DNA (Eftekhar and Mirmohamadi, 2009). Nonetheless, confusing trial examination of S. epidermidis biofilm development is the way that not all disengages encode factors that are thought to enlarge the biofilm arrangement. For example, not all segregate encodes icaADBC; the operon answerable for incorporating PIA. Even though many $S$. epidermidis disconnects are obtained from a characterized biomaterial disease encoding icaADBC, numerous investigations have shown that most commensal $S$. epidermidis isolates obtained from the skin of sound people don't encode icaADBC (Rowson and Townsend, 2016).

\section{Structure of biofilm}

The basic structural units of biofilms are microcolonies, a separate group of bacterial cells implanted into extracellular polysaccharides, microcolonies are the greatest shell rod-like or mushroom formed and they are able to comprise other microbes (van Gestel et al., 2015), reliant on the type of bacteria, microcolonies comprise (10-25) \% cells and (7990) \% matrix of EPS (Maier and Wong, 2015); The quantity of extra polymeric substances increases with age, as well as polysaccharides and ions of metal; the bacterial biofilms consist of proteins, biomolecules like DNA, organic substances and lipids (Decho and Gutierrez, 2017) (Table 2), low rates of nitrogen and carbon, with a very large amount of potassium and phosphates inhibit biofilm production. In contrast, slow growth of bacteria improves biofilm formation (Flemming et al., 2016). The diverse constituents show the integrity of the biofilm and protect the cells from; (i) harsh environmental factors, such as ultraviolet radioactivity, $\mathrm{pH}$ change, osmotic pressure, and desiccation (Delcaru et al., 2016). (ii) A physical barrier counter to defense substances, antibiotic diffusion, or other significant compounds from the host (Matthews et al., 2019), in addition to, the nutrients access to microorganisms surrounding. Bacterial cell microcolonies are separated via channels of water that permit the nutrients, $\mathrm{O}_{2}$, and microbes to flow from a single place to new by rotation of the fluid (Clutterbuck et al., 2007). Biofilms vary in flora, consisting of tiny deposits alternating from simple layer cells to numerous layers comprising aquatic channels (Kumar et al., 2017) moreover, biofilms do not only consist of polymeric matrices and microbial cells but also comprise a diversity of bioparticles containing enzymes, proteins, and ions (Fig. 3). 


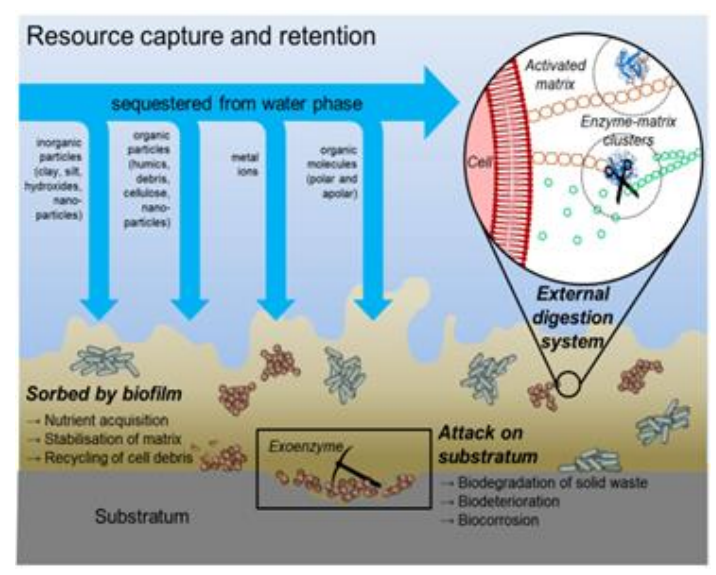

Figure 3. Illustrative demonstration of microbial biofilms consortium components (Vasudevan, 2014).

\section{Biofilm Formation}

Biofilm development reflects a three-step process including several genes, the free-living planktonic state (motile) showed the growth of most bacteria nevertheless, several are capable of showing diverse phenotypes, which vary in physiological features including the structure and metabolic alterations (Levipan et al., 2019). Biofilm develops through multiple routes shared to produce a diversity of adaptive responses and interactions of the organisms inside the biofilms (Green, 2010), and biofilm formation is a difficult process that requires activities of corresponding, and improvement of biofilm occurs in numerous stages. The main stage is attachment, connecting to a surface either external body substantial or environment of human and attempts to adhere to it (Petrova et al., 2016). The original molecular procedures were established by using PCR for the diagnosis of dangerous biofilm-developing strains such as the recognition of the genes that create extracellular polysaccharides; icaD and icaA genes (de Castro Melo et al., 2013). The bacteria communicate by making chemotactic elements otherwise quorum sensing which reflects such as, a main behavior matching mechanism to order gene appearance in agreement with populace density using sign molecules, recognized as autoinducers (Wh et al., 2016), the paths of are made out on a few principal parts, counting microorganism inhabitants, sign molecules, goal genes and activators of protein, which influence biofilm formation (Hu et al., 2018) (Fig. 4). S. epidermidis uses diverse cell envelop related to adhesions named components of bacterial surface identifying molecules of the adhesive environment (Speziale et al., 2014), by distinguishing specific proteins or polymers. for instance, the fibronectin-binding protein (Embp) (Esteban et al., 2014) and GehD of lipase fix on collagen. Additionally, the autolysin AtlE is the cell external position protein included in the establishment of S. epidermidis biofilm, acting as a promoter in the generation of extracellular DNA for the second stage of development before mature biofilm formation (Xu and Siedlecki, 2014). The formation of biofilms is further expected to rely on cell-to-cell adhesion instead of on the cell quantity primarily committed to the surface (Van Houdt and Michiels, 2010; McCall et al., 2019) cell-to-cell adhesion is possibly encouraged by specific connections and not prejudiced by the physicochemical connections of the germs and substrate of attachment (Okshevsky and Meyer, 2015).

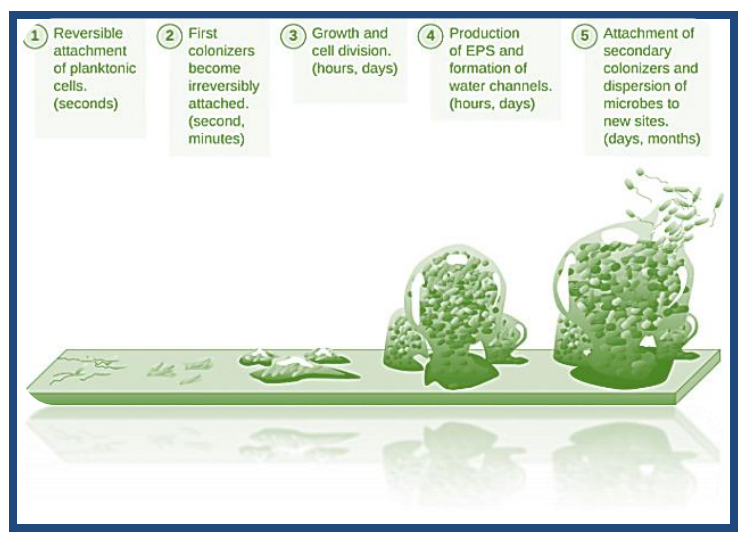

Figure 4. Different phases of biofilm arrangement and advancement including 1. planktonic cell-attached to a surface, 2. cell to cell adhesion, 3. proliferation, 4. cell maturation, and 5. cell releasing to another surface (Hu et al., 2018).

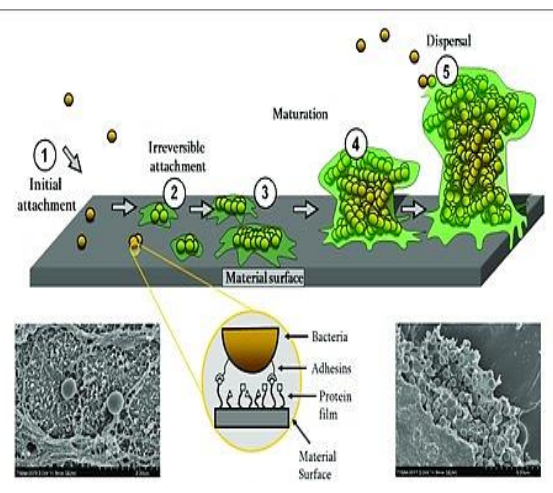

Figure 5. Biofilm formation scheme with scanning electron micrographs of S. epidermidis single cells (lower left) or in biofilm community surrounded by EPS (lower right) on a titanium surface (Moriarly et al., 2011).

The three-dimensional structure of the mature biofilm in (Fig.5) shows that extracellular substances are built with an irregular shape of mushrooms, frequently in the top linked to each other (Chow, 2014). Channels permit a fluid flow containing oxygen and nutrients that can enter bacteria deeper into the layers of biofilm, the biofilm detachment begins as soon as the cell density and mature biofilm reach a confident level, this step is significant in the sense that it 
permits the spread of bacteria and colonies to other sites. This mechanism in staphylococci is controlled by agr quorum sensing (Q.S) system (Adedoyin, 2017).

\section{- Connection}

The free planktonic (Motile) bacteria convert to sessile form before the formation of biofilm where they stick to a favorable surface; such as host tissue or medical device, pili (fimbriae) are specialized organelles that in some cases adhesins are located on it (Hago, 2018), and there are two attachment stages, the alterable-connection occurs when the bacteria are capable of returning to the planktonic form and travel away from the attachment surface. Nonetheless, at the irreversible stage, the organisms adhere and biofilm formation is initiated (Petrova and Sauer, 2016).

\section{- Microcolonies Development}

Collective cells bond on the surface at that time divide into daughter cells, from the point of attachment they multiply upward and outward to form clusters of cells, extracellular polymeric substances (EPS) and molecules of quorum sensing are produced by the dividing cells, hence accumulating cells in biofilms and microcolonies attaches to surface on which it is formed (Giupponi and Candiani, 2017), increasing organisms number cause microcolonies become bigger and quantity of EPS increased as well increasing of signaling molecules and in this stage, EPS are produced within microcolonies (Karimi et al., 2015). The structure of a fully mature biofilm consists of a polymer matrix, bacterial cells, and channels of interstitial water that help the waste and nutrient exchange due to the biofilm spreading into the neighboring location (Sauer et al., 2007).

- Separation and dispersal

The height population density inside a complete biofilm encourages bacteria to automatically detach from the biofilm by secretion of chemical substances (Kaplan, 2010), once the bacteria react to biological substances and are secreted by them detachment occurs, for example, degradative enzymes, signaling molecules, proteins and oxidative or nitro tension-inducing molecules such as nitric oxide (NO) created from metabolic procedures inside a biofilm (Skariyachan et al., 2018). The polymer matrix is cleaved into short oligosaccharides by the degradative enzyme produced by biofilm organisms due to increased biofilm organism's detachment (Cellini, 2010), which are prompting factors for bacterial biofilm dispersal by increasing bacterial growth and quorum sensing production, which generally help the processes of dispersal inside the biofilm (Emerenini et al., 2015). Moreover, biofilm detachment is caused by nutrient starvation, hence the processes of detachment improve the biofilm sloughing and sessile organisms switching inside a biofilm, separate isolated bacteria from other locations continue to form biofilms (Lyons, 2012), biofilm dispersal causes infections to spread in the host which occasionally might cause thromboembolism and may result in death Brading et al., 1995).

\section{B. Quorum Sensing [QS] Cell-to-cell Communication}

Quorum sensing is analogous to assessment-making method types, which performance is corresponding done a "chemical vocabulary" and used to the signaling of a cell to cell and uniform among species (Baroncini et al., 2019). Communication of cell-to-cell among microbes including autoinducers (AIs) which are the small hormones like molecule, organisms in the interior environment by signaling molecules production able to full formation of biofilm, and established in lacking strains were capable of causing infections and less antimicrobial susceptibility (Lyon, 2015) (fig.6). However, several virulence factors are not related to molecules (Senturk et al., 2012). Quorum sensing depends on phenotypes diverge along with the organism's isolation site. Staphylococci autoinducers (AIs) is a peptide and when AIs level reaches a convinced threshold the bacteria gene expression alters (Pérez-Velázquez et al., 2016) (fig.7). Furthermore, quorum sensing investigation of S.aureus has been completed, but similar developments have been established in further staphylococci genes, such $S$. epidermidis (Reddy et al., 2019).

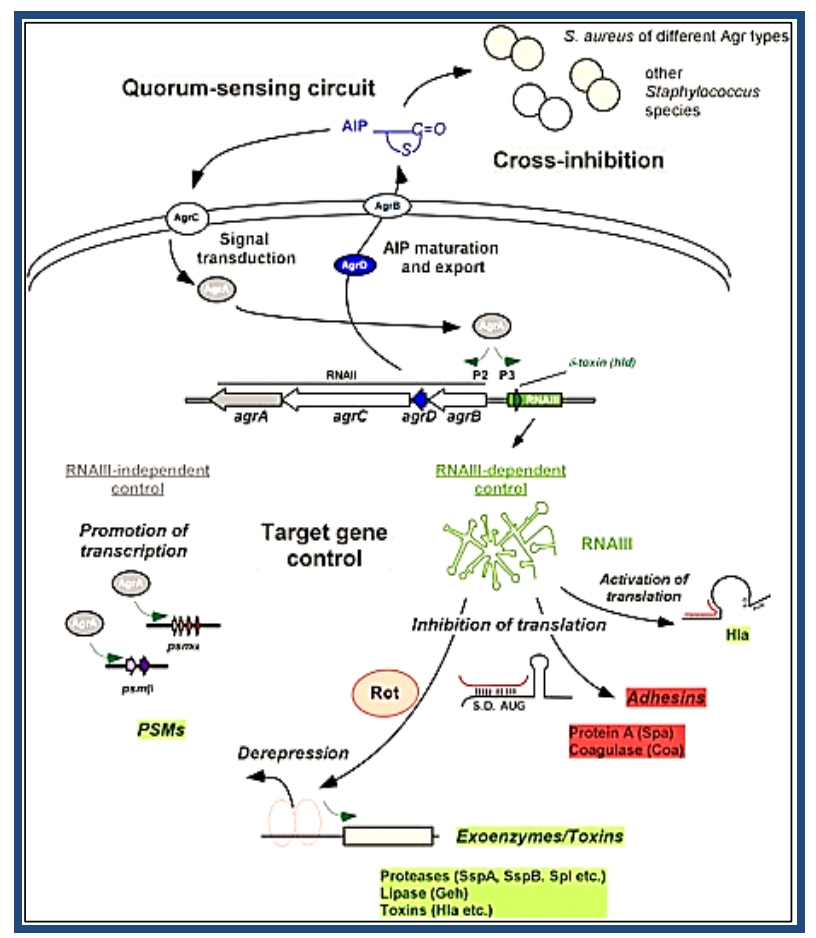

Figure 7. Diagram summary of agr QS arrangement in Staphylococcus spp. The quorum-sensing is controlled by released AIP signal from AgrD by the AgrB and then when the AIP reaches a specific concentration the AgrC-AgrA activates the transcription, Agr inhibition occurs in other bacteria Agr groups and is regulated by RNAIII. RNAIII inhibits the translation of target gene control in most states. RNAIII promote PSM transcription (Le and Otto, 2015). 
Staphylococci quorum sensing system is under the control of accessory gene regulator (agr) (Kane, 2017). The upregulation of exo-protein synthesis and downregulation of surface proteins is mediated by the bacteria. Therefore, a system of decoration gene regulator controls in $S$. epidermidis is an important portion of the chromosomal genes (approximately16\%) such as genes involved in virulence, separation of cells, and metabolic alterations (Kane et al., 2018). The size of agr gene consists of four accessory genes, regulator genes (agrB, $\operatorname{agrD}, \operatorname{agrC}$ and agrA) and it is a complex gene approximately $3.5 \mathrm{~kb}$, all regulator genes transcribed via RNAII. The expression of this autoinducing peptide is regulated by $\operatorname{agrC}$ and $\operatorname{agrA}$, while $a g r D$ encodes for autoinducing peptide (AIP), which is exported and modified by $a g r B$. The gene for delta-toxin ( hld) is placed adjacent to the agr complex and transcribe by RNAIII (Marroquin et al., 2019).

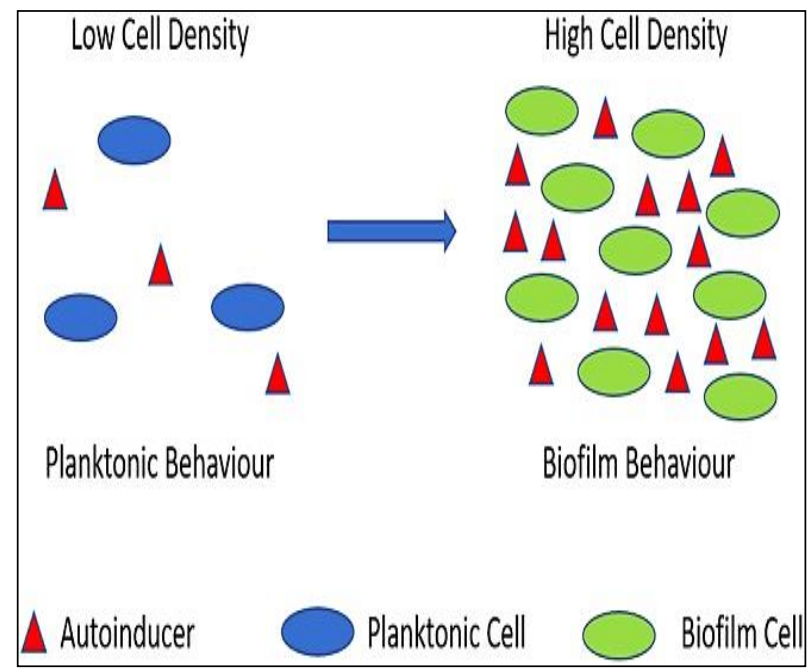

Figure 6. Quorum sensing illustration. During planktonic cell growth (blue ovals), the relative amount of autoinducers (red triangles) is proportionally low. As cells enter a densely populated mode of growth (green ovals) the relative proportion of autoinducers increases (Verderosa et al., 2019).

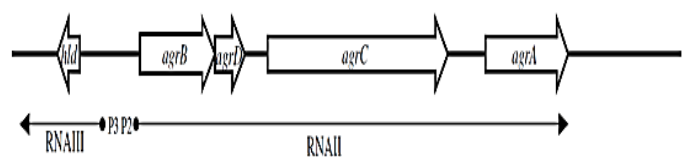

Figure 8. various genes forming the $a g r$ intricate and then ear by hld gene, with the transcriptions RNAII and RNAIII marked (Halebeedu et al., 2014).

\section{IMMUNE RESPONSE}

Throughout the body, a large and complex series of immune system elements are widely distributed including several functions the protection against pathogens and responses to foreign materials (Aslani and Ghobadi, 2016). Immune responses include two classes: non-specific or innate immune responses and acquired or adaptive immune responses, which are highly specific to a specific pathogen. Humoral immunity includes molecules in biological fluid solutions (Mak et al., 2013; Liu et al., 2019b), humoral immunity (also called the antibody-mediated system) is the part of immunity that is mediated via macromolecules present in extracellular fluids, such as secreted antibodies, complement proteins, and confident antimicrobial peptides (Magiri, 2019). When immunoglobulin binds, the infectious agents deactivate; hence, cellular immunity includes the expansion of immune cells that are capable of recognizing, binding, and killing additional cells that were previously infected via foreign infectious agents (Augustyniak et al., 2017; Land, 2018). Humoral immunity involves complement and antibodies; thus, cytokines are produced chiefly through immune cells, and in almost every aspect of immunity and inflammation, cytokines are included (Parham, 2014; Brook and Dobson, 2015). IL-6 is a pro-inflammatory cytokine that plays an important role among pro-inflammatory cytokines in immunity similarly, a pro-inflammatory chemokine Interleukin-8 is secreted from a variety of cell types including leukocytes, endothelial cells, cancer cells, and fibroblasts (Molina et al., 2010).

Bacteria produce a chemical substance within the biofilm that is resistant to antimicrobials and immune mechanisms of the body. Biofilm formation matures at a sluggish rate which improves their ability to resist host immune appliances and antimicrobial interference (Golob, 2016). Biofilm-produced bacteria cause infections via means of their protection from antimicrobials and the body's immune system (Liu et al., 2019a). In normal human serum, biofilm bacteria are less susceptible to phagocytic killing after opsonization (Banerjee et al., 2020). Several studies have been established the chief role of biofilms in overcoming the immune system and biofilm ability to resist the host immune mechanism elements (Alhede et al., 2014), which is one of the causes of diseases, and biofilms importance is seldom determined through a personality's specific immune system (Bjarnsholt et al., 2013). The polymeric matrix is the first defense of the pathogen, and the presence of EPS protects the microbes from the phagocytic process by preventing phagocytic and neutrophil cells from engulfing microbial cells (Arciola et al., 2012). Because of the inefficiency of opsonization to the bacteria that form biofilms inside the body, the levels of killing decreased by the phagocytic cells; polymorphonuclear (PMNs) of the positive wild-type bacteria to form biofilms (Kırmusaoğlu, 2016). Destruction of S. epidermidis biofilms by immune defense fewer than planktonic cells which can be opsonized with immunoglobulin (Priyanka, 2014). The diffusion of Anti-PIA/PNAG antibodies into the biofilm of $S$. epidermidis is sufficient to allow opsonization (Rohde et al., 48 
2010) regardless, of the mechanism of biofilm, accumulation related proteins, polysaccharide intercellular connections, and extracellular matrix requisite proteins. S. epidermidis from the collected biofilm cells caused a minor inflammatory response by macrophages which was more than the scatter biofilm formed by microbes or mutant biofilms. Undesirable, which may show additional mechanisms of $S$. epidermidis in chronic infection aid under the immune system (Sparling, 2013).

The ability of biofilms to defend microorganisms against host innate immunity is essential for $S$. epidermidis pathogenesis, it protects $S$. epidermidis from phagocytosis by decreasing the opsonization of $\mathrm{IgG}, \mathrm{C} 3 \mathrm{~b}$ connect to the surface of bacteria, and stimulation of the complement cascade intermediated via PIA biofilm (Li et al., 2018), S. epidermidis decreasing cytokine production by animal mononuclear cells (for instance monocytes) invitro (Kuwahara et al., 2005). PIA and non-PIA protect $S$. epidermidis biofilm from phagocytosis, by the disconnect between PRRs and bacteria on the leukocytes (design recognition receptors), In addition to stimulating a weak NFкB (nuclear factor kappa-light-chain-enhancer of activated B cells) mediated macrophage inflammatory immune, the absence of connection between the bacteria and macrophages, as well happenings altering the macrophage role look to yield portion in the host miscarriage to eliminate S. epidermidis through infections (Granslo, 2012).

The bacterial biofilm phenotype is arranged in various features by planktonic development to improve the antibacterial resistance and variance in gene expression, in addition to the ability of biofilm to defend local bacteria from the violence of the immune system (Otto, 2014). Antibody production can be stimulated by the release of antigens through mature biofilms, but the bacteria inside the membrane will be resistant to these defense mechanisms. Mature biofilms can discharge antigens and encourage the creation of antibodies, nonetheless, the bacteria that are inhibited inside the biofilm are resistant to these attack appliances. Moreover, PNAG defends planktonic $S$. epidermidis in contrast to antibody-independent phagocytosis, in that PNAG is improved by opsonization, which includes complement and immunoglobulin mediated phagocytosis (Bhattacharya et al., 2015). The mechanisms of bacterial resistance in biofilms to immunity are known by the antibodies diffusion assessed through biofilm. Antibodymediated phagocytic destruction of the planktonic cells in $S$. epidermidis biofilm cells by the use of a rabbit antibody against PNAG (Boisvert et al., 2016), these immunoglobulins are opsonic and defend against infection with planktonic cells of PNAG positive $S$. epidermidis, the immune response to PNAG promptly enters the biofilm and is connected to similar parts in the biofilm, a lectin recognized to tie biofilm parts (Cerca et al., 2006). On the other hand, the biofilm cell has additional impervious to opsonic slaughtering than planktonic partners even though creating more PNAG per cell than planktonic cells, Biofilm removes repressed opsonic destroy intervened by antibody to PNAG, the PNAG antigen inside biofilm matrix inhibits antibody binding closely to surface bacteria, which required for capable opsonic killing (Shahrooei et al., 2012).

Expanding obstruction of biofilm cells to opsonic murdering interceded by another defensive counteracting agent is expected not to be a biofilm-explicit phenotype, whereas significant heights of antigen inside bacterial biofilms that inhibit bacterial opsonization through the immune response, the matrix of S. epidermidis biofilms is essentially out of the enormous exopolysaccharide PNAG (Moser et al., 2017). The creation of PNAG is essential for S. epidermidis biofilm arrangement and are produced via gene result of the icaADBC gene group, therefore the creation of pNAG/pIA and biofilm development are controlled by different sigma factor sB (Sabaté Brescó et al., 2017), opsonic antibodies to PNAG intercede assurance against fundamental disease by $S$. epidermidis where it's called capsular polysaccharide/attachment (Kırmusaoğlu, 2016). As a result, the biofilm matrix can shield microscopic organisms from immunoglobulin-mediated phagocytosis in the proximity of antibodies opsonically dynamic versus planktonic cells. An enormous measure of PNAG antigen exists inside the matrix limiting antibodies official to the bacterial cell surface, which it requests to advance opsonic slaughtering just as more PNAG produced per cell inside the biofilm matrix (Skurnik et al., 2016), this supports the conclusion that this enormous amount of antigen can inhibit antibody binding to the bacterial cell surface (Cywes-Bentley et al., 2013). PNAG is a secure planktonic microbial against the autonomous phagocytic immune response and it creates the impression that even in the proximity of opsonic antibodies to PNAG, the overabundance of the objective antigen inside the biofilm can forestall productive opsonic murdering (Veerachamy et al., 2014).

\section{A. Biofilm-associated infections of S. epidermidis prevention and treatment}

Biofilms protect microbial cells from serious ecological situations, such as the toxicity of metals, ultraviolet introduction, lack of hydration and saltiness, acid exposure, and anti-toxins or other antimicrobial operators just as phagocytosis (Ahmed et al., 2020). The essential problem with bacterial biofilm infections is affinity to clearance of resistance by antimicrobial agents and host immune system when compared to their free (planktonic) partners. Microscopic organisms inside a biofilm (sessile) are up to 1000 times progressively resistant to anti-microbial causes (Turkina and Vikström, 2019); thus, the elements that add to overall biofilm resistance are: 
- Diminishing the development ratio of microbes in a biofilm creation that is less inclined to antimicrobials by goal metabolic paths.

- Obligate diffusion of antimicrobial composites (di Biase $e t$ al., 2019).

An unmistakable phenotype that presents resistance to antimicrobials, host immune resistance and encourages horizontal gene transmission, numerous systems utilized to battle the biofilm diseases can be summarized in (Grimaldi et al., 2020).

The preventive methodologies target are; functional particles, systems of the gene, and administrative, which control the beginning time of biofilm improvement; different materials are utilized to inhibit initial biofilm formation and disrupt the maturation biofilm, for example, catalysts are prompting dis-regulation of particles balancing out the biofilm design and causing disintegration of the matrix of the biofilm (Mahamuni-Badiger et al., 2020), Moreover, alteration of biomaterial surface which prevents the colonization of bacteria through applying biomaterials that have antimicrobial activity, wholly these methodology depends on prophylactic utilizing of antitoxin as well as submersion, covering and loading of a matrix (Darwin, 2011). Thus, to prevent microbial colonization on the surface of the clinical device is the major goal and then the bacterial establishment with biofilm formation stopped (Khan et al., 2020; Subhi et al., 2020), therefore antimicrobial agents can decrease the biofilm stratum next to sub-inhibitory concentrations. Sub inhibitory focuses of several antibiotics that stay viewing together impede and stimulate the formation of coagulase-negative staphylococci biofilm, these effects seeming to be based on antimicrobial agent type and the bacterial strain (Mohapatra et al., 2020).

\section{CONCLUSIONS}

Biofilm is bacterial colonies aggregation, commonly of multiple species that create a protective EPS and forms a micro-environment inside, conducive to persistence and finally leads to chronic infection in the form of pulmonary infections, stones of kidney, cutaneous non-healing wounds, and endocarditis. Bacteria undergo genetic changes when exposed to environmental stressors that promote the formation of biofilm. Biofilms consist of multiple elements, for example, extracellular DNA, proteins, polysaccharides, and water/ biosurfactants, completely which have unique functional and structural characters that create the biofilm formation and its properties. Biofilms are the main cause of chronic disease because of the signals secretion that blocks an appropriate host immune response. Whereas, each species of biofilm is diverse in specific properties, make-up, and antibiotics response. In general, treatment of biofilms are extremely difficult by antibiotics because the EPS block the diffusion of the antibiotic and create a microenvironment that allows gene transfer between the cells inside the biofilm, thus the cells become more resistant, slowing metabolically, and finally dispersion or escape to establish a new biofilm at different places inside the body.

\section{REFERENCES}

Adedoyin, A.E. (2017). Isolation and characterization of carotenoid producing microalgae from KwaZulu-Natal (South Africa) (Master Thesis).

Ahmed, B., Ameen, F., Rizvi, A., Ali, K., Sonbol, H., Zaidi, A., ... \& Musarrat, J. (2020). Destruction of cell topography, morphology, membrane, inhibition of respiration, biofilm formation, and bioactive molecule production by nanoparticles of $\mathrm{Ag}, \mathrm{ZnO}, \mathrm{CuO}, \mathrm{TiO} 2$, and Al2O3 toward beneficial soil bacteria. ACS omega, 5(14), 7861-7876.

Alhede, M., Bjarnsholt, T., Givskov, M., Alhede, M. (2014). Pseudomonas aeruginosa biofilms, mechanisms of immune evasion. Advances in applied microbiology, 86,1-40.

Arciola, C.R., Campoccia, D., Speziale, P., Montanaro, L., Costerton, J.W. (2012). Biofilm formation in Staphylococcus implant infections. A review of molecular mechanisms and implications for biofilm-resistant materials. Biomaterials, 33(26), 5967-5982.

Aslani, B.A., Ghobadi, S. (2016). Studies on oxidants and antioxidants with a brief glance at their relevance to the immune system. Life sciences, 146, 163-173.

Augustyniak, D., Majkowska-Skrobek, G., Roszkowiak, J., DorotkiewiczJach, A. (2017). Defensive and offensive cross-reactive antibodies elicited by pathogens, The Good, the Bad and the Ugly. Current medicinal chemistry, 24(36), 4002-4037.

Banerjee, D., Shivapriya, P.M., Gautam, P.K., Misra, K., Sahoo, A.K., Samanta, S.K. (2020). A review on basic biology of bacterial biofilm infections and their treatments by nanotechnology-based approaches. Proc. Natl. Acad. Sci., India, Sect. B Biol. Sci. 90, 243259.

Baroncini, M., Silvi, S., Credi, A. (2019). Photo-and redox-driven artificial molecular motors. Chemical reviews, 120(1), 200-268.

Bastos, M.D.C.D.F., Coutinho, B.G., Coelho, M.L.V. (2010). Lysostaphin, a staphylococcal bacteriolysin with potential clinical applications. Pharmaceuticals, 3(4), 1139-1161.

Bermudes, D.G. (2020). "Live bacterial vaccines resistant to carbon dioxide (CO2), acidic $\mathrm{pH}$ and/or osmolarity for viral infection prophylaxis or treatment." U.S. Patent: USP20190110188722.

Bhattacharya, M., Wozniak, D.J., Stoodley, P., Hall-Stoodley, L. (2015). Prevention and treatment of Staphylococcus aureus biofilms. Expert review of anti-infective therapy, 13(12), 1499-1516.

Bjarnsholt, T., Alhede, M., Alhede, M., Eickhardt-S $\varnothing$ rensen, S.R., Moser, C., Kühl, M., Høiby, N. (2013). The in vivo biofilm. Trends in microbiology, 21(9), 466-474.

Bocian, A., Ciszkowicz, E., Hus, K.K., Buczkowicz, J., Lecka-Szlachta, K., Pietrowska, M., Legáth, J. (2020). Antimicrobial Activity of Protein Fraction from Naja ashei Venom Against Staphylococcus epidermidis. Molecules, 25(2), 293.

Boisvert, A.A., Cheng, M.P., Sheppard, D.C., Nguyen, D. (2016). Microbial biofilms in pulmonary and critical care diseases. Annals of the American Thoracic Society, 13(9), 1615-1623.

Bottagisio, M., Barbacini, P., Bidossi, A., Torretta, E., deLancey-Pulcini, E., Gelfi, C., Capitanio, D. (2020). Phenotypic Modulation of Biofilm Formation in a Staphylococcus epidermidis Orthopedic Clinical Isolate Grown Under Different Mechanical Stimuli, Contribution from a Combined Proteomic Study. Frontiers in microbiology, 11, 565914.

Brading, M., Jass, J., Lappin-Scott, H. (1995). Dynamics of Bacterial Biofilm Formation. In H. Lappin-Scott J. Costerton (Eds.), Microbial 
Biofilms (Biotechnology Research, pp. 46-63). Cambridge: Cambridge University Press.

Brook, C.E., Dobson, A.P. (2015). Bats as 'special' reservoirs for emerging zoonotic pathogens. Trends in microbiology, 23(3), 172-180.

Cellini, A. (2010). Role of reactive oxygen and nitrogen species in the response of Prunus spp. to bicarbonate (Doctoral dissertation, alma). http://amsdottorato.unibo.it/id/eprint/2530.

Cheung, G.Y., Rigby, K., Wang, R., Queck, S.Y., Braughton, K.R., Whitney, A.R., Otto, M. (2010). Staphylococcus epidermidis strategies to avoid killing by human neutrophils. PLoS pathogens, 6 (10). e1001133.

Chow, B.Y.L. (2014). Bioactive glass microspheres with controlled drug fluting capabilities for use in synthetic skin scaffolds (Master's thesis, University DE Rennes).

Clutterbuck, A.L., Woods, E.J., Knottenbelt, D.C., Clegg, P.D., Cochrane, C.A., Percival, S. L. (2007). Biofilms and their relevance to veterinary medicine. Veterinary microbiology, 121(1-2), 1-17.

Costa, E.M., Silva, S., Veiga, M., Tavaria, F.K., Pintado, M.M. (2018). Chitosan's biological activity upon skin-related microorganisms and its potential textile applications. World Journal of Microbiology and Biotechnology, 34 (7), 93.

Cywes-Bentley, C., Skurnik, D., Zaidi, T., Roux, D., De Oliveira, R.B., Garrett, W.S., Rey, A. (2013). Antibody to a conserved antigenic target is protective against diverse prokaryotic and eukaryotic pathogens. Proceedings of the National Academy of Sciences, 110 (24)

Darwin, M. (2011). Induction of Hypothermia in the Cryonics Patient, Theory and Technique, Part 2 http://chronopause.com/chronopause.com/index.html.

Decho, A.W., Gutierrez, T. (2017). Microbial extracellular polymeric substances (EPSs) in ocean systems. Frontiers in microbiology, 8, 922.

Delcaru, C., Alexandru, I., Podgoreanu, P., Grosu, M., Stavropoulos, E., Chifiriuc, M. C., Lazar, V. (2016). Microbial Biofilms in Urinary Tract Infections and Prostatitis: Etiology, Pathogenicity, and Combating strategies. Pathogens (Basel, Switzerland), 5(4), 65.

di Biase, A., Kowalski, M.S., Devlin, T.R., Oleszkiewicz, J.A. (2019). Moving bed biofilm reactor technology in municipal wastewater treatment, A review. Journal of environmental management, 247, 849866.

Wang, D., Wei, Y., Shi, L., Khan, M. Z., Fan, L., Wang, Y., Yu, Y. (2020). Genome-wide DNA methylation pattern in a mouse model reveals two novel genes associated with Staphylococcus aureus mastitis. AsianAustralasian journal of animal sciences, 33(2), 203-211.

Duffus, J., Templeton, D.M., Schwenk, M. (2017). Comprehensive glossary of terms used in toxicology, First edition: Royal Society of Chemistry.

Eftekhar, F., Mirmohamadi, Z. (2009). Evaluation of biofilm production by Staphylococcus epidermidis isolates from nosocomial infections and skin of healthy volunteers. International Journal of Medicine and Medical Sciences, 1(10), 438-441.

Emerenini, B.O., Hense, B.A., Kuttler, C., Eberl, H.J. (2015). A Mathematical Model of Quorum Sensing Induced Biofilm Detachment. PloS one, 10(7), e0132385.

Essa, R.H., Hussain, S.S., Tektook, N.K. (2015). Relationship between Ica gen and hemaaglutination in Staphylococcus epidermidis form biofilm. Journal of Genetic and Environmental Resources Conservation, 3(1), 74-83.

Esteban, J., Pérez-Tanoira, R., Pérez-Jorge-Peremarch, C., Gómez-Barrena, E. (2014). Bacterial adherence to biomaterials used in surgical procedures, In Microbiology for Surgical Infections, 41-57. Academic Press.

Fisher, R.A., Gollan, B., Helaine, S. (2017). Persistent bacterial infections and persister cells. Nature reviews. Microbiology, 15(8), 453-464.

Flemming, H.C., Wingender, J., Szewzyk, U., Steinberg, P., Rice, S.A., Kjelleberg, S. (2016). Biofilms: an emergent form of bacterial life. Nature reviews. Microbiology, 14(9), 563-575.
Fontana, C., Favaro, M. (2018). Coagulase-positive and coagulase-negative staphylococci in human disease, In Pet-To-Man Travelling Staphylococci, First edition, 25-42. Academic Press.

Foster, T. J., Geoghegan, J.A., Ganesh, V.K., Höök, M. (2014). Adhesion, invasion and evasion: the many functions of the surface proteins of Staphylococcus aureus. Nature reviews. Microbiology, 12(1): 49-62.

Giupponi, E., Candiani, G. (2017). Interaction of polymeric biomaterials with bacteria (static). In Characterization of Polymeric Biomaterials, Elsevier, Woodhead Publishing. 317-337.

Golob, S. (2016). innovative antibacterial systems for orthopedic and traumatology applications. Medicine, Corpus ID: 80598043 http://hdl.handle.net/11368/2907984.

Gomes, F., Teixeira, P., Oliveira, R. (2014). Mini-review: Staphylococcus epidermidis as the most frequent cause of nosocomial infections: old and new fighting strategies. Biofouling, 30(2), 131-141.

Gonçalves, V.A.D.S. (2016). Survival of Staphylococcus epidermidis biofilm-released cells in human blood and plasma (Doctora dissertation, Universidade do Minho).

Goneau, L.W. (2014). Sub-Inhibitory Antibiotics Enhance Virulence, Persistence, and Pathogenesis of Uropathogens. ASM journals mBio, 6(2), e00356-15.

Halebeedu, P.P., Kumar, G.S., Gopal, S. (2014). Revamping the role of biofilm regulating operons in device-associated Staphylococci and Pseudomonas aeruginosa. Indian J Med Microbiol., 32(2), 112-23.

Granslo, H.N. (2012). Staphylococcus epidermidis-virulence factors and innate immune response. https://munin.uit.no/bitstream/handle/10037/5051/thesis.pdf?sequence $=11 \&$ is Allowed $=\mathrm{y}$.

Green, C.S. (2010). Characterizing cell-cell and cell-surface interactions in the rhizobacterium Azospirillum brasilense. (Master thesis, University of Tennessee,Knoxville). https://trace.tennessee.edu/utk_gradthes/712.

Grimaldi, A., Eguileor, M., Tettamanti, G., Valvassori, R., Baranzini, N., Bruno, D., Montali, A., Pulze, L. (2020). XXIst scientific meeting of the Italian Association of Developmental and Comparative Immunobiology (IADCI), 12-14 February 2020, Department of Biotechnology and Life sciences (DBSV), University of Insubria, Varese, Italy. ISJ-Invertebrate Survival Journal, 9-23.

Hago, Z.E.M. (2018). Antimicrobial Activity of Acacia Nilotica Bee Honey on Biofilms Forming Staphylococcus aureus isolated from Wound Swabs (Doctoral dissertation, Sudan University of Science \& Technology). http://repository.sustech.edu/handle/123456789/22828.

Henderson, B., Poole, S., \& Wilson, M. (1996). Bacterial modulins: a novel class of virulence factors which cause host tissue pathology by inducing cytokine synthesis. Microbiological reviews, 60(2), 316-341.

Hu, X., Huang, Y.Y., Wang, Y., Wang, X., Hamblin, M.R. (2018). Antimicrobial Photodynamic Therapy to Control Clinically Relevant Biofilm Infections. Frontiers in microbiology, 9, 1299.

Josse, J., Valour, F., Maali, Y., Diot, A., Batailler, C., Ferry, T., Laurent, F. (2019). Interaction Between Staphylococcal Biofilm and Bone: How Does the Presence of Biofilm Promote Prosthesis Loosening? Frontiers in microbiology, 10, 1602

Jyoti, K., Malik, G., Chaudhary, M., Sharma, M., Goswami, M., Katare, O. P., Singh, S.B., Madan, J. (2020). Chitosan and phospholipid assisted topical fusidic acid drug delivery in burn wound: Strategies to conquer pharmaceutical and clinical challenges, opportunities and future panorama. International journal of biological macromolecules, 161 , $325-335$

Kane, T.L. (2017). Examination of a New Virulence Factor in a Select Strain of Methicillin Resistant Staphylococcus Aureus (Doctoral dissertation, University of Notre Dame). https://curate.nd.edu/show/sx61dj55j0b.

Kane, T.L., Carothers, K.E., Lee, S.W. (2018). Virulence Factor Targeting of the Bacterial Pathogen Staphylococcus aureus for Vaccine and Therapeutics. Current drug targets, 19(2),111-127. 
Kaplan, J.B. (2010). Biofilm dispersal: mechanisms, clinical implications, and potential therapeutic uses. Journal of dental research, 89(3), $205-$ 218.

Karimi, A., Karig, D., Kumar, A., Ardekani, A.M. (2015). Interplay of physical mechanisms and biofilm processes: review of microfluidic methods. Lab on a chip, 15(1), 23-42.

Khan, F., Pham, D., Oloketuyi, S.F., Kim, Y.M. (2020). Antibiotics Application Strategies to Control Biofilm Formation in Pathogenic Bacteria. Current pharmaceutical biotechnology, 21(4), 270-286.

Kırmusaoğlu, S. (2016). Staphylococcal biofilms, Pathogenicity, mechanism and regulation of biofilm formation by quorum sensing system and antibiotic resistance mechanisms of biofilm embedded microorganisms. Microbial Biofilms-Importance and Applications, Edited volume, Dhanasekaran $D$, Thajuddin $N$, editors. Intech, Croatia, 189-209.

Kucinskas, M. (2017). The effect of sub-inhibitory concentrations of antibiotics on the regulation of eDNA in Staphylococcal biofilms. (Master thesis, Western Sydney University) http://hdl.handle.net/1959.7/uws:45604.

Kumar, V., Sachan, T.K., Gupta, U.D. (2017). Emerging Concept and Technology on Mycobacterial Biofilm. GSL Journal of Clinical Pathology, 1(1).

Kuwahara, K., Kitazawa, T., Kitagaki, H., Tsukamoto, T., \& Kikuchi, M. (2005). Nadifloxacin, an antiacne quinolone antimicrobial, inhibits the production of proinflammatory cytokines by human peripheral blood mononuclear cells and normal human keratinocytes. Journal of dermatological science, 38(1), 47-55.

Land W.G. (2018). Innate Immune Recognition Molecules. In: DamageAssociated Molecular Patterns in Human Diseases. Springer, Cham. https://doi.org/10.1007/978-3-319-78655-1_5.

Le, K., Otto, M. (2015). Quorum-sensing regulation in staphylococci-an overview. Frontiers in microbiology, 6, 1174.

Levipan, H.A., Tapia-Cammas, D., Molina, V., Irgang, R., Toranzo, A.E., Magariños, B., Avendaño-Herrera, R. (2019). Biofilm development and cell viability, An undervalued mechanism in the persistence of the fish pathogen Tenacibaculum maritimum. Aquaculture, 511, 734267.

Li, X., Wu, B., Chen, H., Nan, K., Jin, Y., Sun, L., Wang, B. (2018). Recent developments in smart antibacterial surfaces to inhibit biofilm formation and bacterial infections. Journal of Materials Chemistry B, 6 (26), 4274-4292.

Liu, Y., Shi, L., Su, L., van der Mei, H.C., Jutte, P.C., Ren, Y., Busscher, H. J. (2019 a). Nanotechnology-based antimicrobials and delivery systems for biofilm-infection control. Chemical Society Reviews, 48(2), 428446.

Liu, Y., Zhang, J., Wang, S., Guo, Y., He, T., Zhou, R. (2019 b). A novel adjuvant "sublancin" enhances immune response in specific pathogenfree broiler chickens inoculated with Newcastle disease vaccine. Journal of immunology research, 2019, 1016567, 7 pages.

Lood, R., Waldetoft, K.W., Nordenfelt, P. (2015). Localization-triggered bacterial pathogenesis. Future microbiology, 10(10), 1659-1668.

Lyon, P. (2015). The cognitive cell, bacterial behavior reconsidered. Frontiers in microbiology, 6, 264.

Lyons, K. M. (2012). Microbial adhesion to maxillary obturator materials (Doctoral dissertation, University of Otago). http://hdl.handle.net/10523/2500.

Magiri, R.B. (2019). Innate immune responses activated by the adjuvant poly [di (sodium carboxylatoethylphenoxy) phosphazene](pcep) in pigs (Doctoral dissertation, University of Saskatchewan). https://harvest.usask.ca/handle/10388/12208.

Mahamuni-Badiger, P.P., Patil, P.M., Badiger, M.V., Patel, P.R., ThoratGadgil, B. S., Pandit, A., Bohara, R.A. (2020). Biofilm formation to inhibition: Role of zinc oxide-based nanoparticles. Materials science \& engineering. C, Materials for biological applications, 108, 110319.

Maier, B., Wong, G. (2015). How Bacteria Use Type IV Pili Machinery on Surfaces. Trends in microbiology, 23(12), 775-788.
Mak, T.W., Saunders, M.E., Jett, B.D. (2013). Primer to the immune response. First edition, Academic Cell.

Marroquin, S., Gimza, B., Tomlinson, B., Stein, M., Frey, A., Keogh, R.A., Zapf, R., Todd, D.A., Cech, N.B., Carroll, R. K., Shaw, L.N. (2019). MroQ Is a Novel Abi-Domain Protein That Influences Virulence Gene Expression in Staphylococcus aureus via Modulation of Agr Activity. Infection and immunity, 87(5), e00002-19.

Matthews, K. R., Kniel, K. E., \& Montville, T. J. (2019). Food microbiology, an introduction. Fourth edition, John Wiley \& Sons.

McCall, A.D., Pathirana, R.U., Prabhakar, A., Cullen, P.J., Edgerton, M. (2019). Candida albicans biofilm development is governed by cooperative attachment and adhesion maintenance proteins. npj Biofilms and Microbiomes, 5(21).

Mehlin, C., Headley, C.M., Klebanoff, S.J. (1999). An inflammatory polypeptide complex from Staphylococcus epidermidis: isolation and characterization. The Journal of experimental medicine, 189(6), 907918.

de Castro Melo, P., Ferreira, L. M., Filho, A. N., Zafalon, L. F., Vicente, H. I., \& de Souza, V. (2013). Comparison of methods for the detection of biofilm formation by Staphylococcus aureus isolated from bovine subclinical mastitis. Brazilian journal of microbiology: [publication of the Brazilian Society for Microbiology], 44(1), 119-124.

Miyoshi, Y., Okada, S., Uchimura, T., Satoh, E. (2006). A mucus adhesion promoting protein, MapA, mediates the adhesion of Lactobacillus reuteri to Caco-2 human intestinal epithelial cells. Bioscience, biotechnology, and biochemistry, 70(7), 1622-1628.

Mohapatra, S.S., Frisina, R.D., Mohapatra, S., Singh, M., Phan, M.H. (2020). Proceedings of the 2019 Nano Florida International Conference Held at the University of South Florida, Tampa, FL. Appl. Sci., 10(14), 4851.

Molina, P.E., Happel, K.I., Zhang, P., Kolls, J.K., Nelson, S. (2010). Focus on: Alcohol and the immune system. Alcohol research \& health: the journal of the National Institute on Alcohol Abuse and Alcoholism, 33(1-2), 97-108.

Moriarty T. F., Poulsson A. H. C., Rochford E. T. J., Richards R. G. (2011). 4.407 - bacterial adhesion and biomaterial surfaces A2 in Comprehensive Biomaterials, ed Ducheyne P. (Oxford: Elsevier;), 75100.

Moser, C., Pedersen, H. T., Lerche, C. J., Kolpen, M., Line, L., Thomsen, K., Høiby, N., \& Jensen, P. Ø. (2017). Biofilms and host response - helpful or harmful. APMIS, 125(4), 320-338.

Okshevsky, M., Meyer, R.L. (2015). The role of extracellular DNA in the establishment, maintenance and perpetuation of bacterial biofilms. Critical reviews in microbiology, 41(3), 341-352.

Oliveira, D., Borges, A., Simões, M. (2018). Staphylococcus aureus Toxins and Their Molecular Activity in Infectious Diseases. Toxins, 10(6), 252 .

Ong, T.H., Chitra, E., Ramamurthy, S., Ling, C., Ambu, S.P., Davamani, F. (2019). Cationic chitosan-propolis nanoparticles alter the zeta potential of $S$. epidermidis, inhibit biofilm formation by modulating gene expression and exhibit synergism with antibiotics. PloS one, 14(2), $\mathrm{e} 0213079$

Otto, M. (2009). Staphylococcus epidermidis-the 'accidental' pathogen. Nature reviews. Microbiology, 7(8), 555-567.

Otto M. (2014). Staphylococcus epidermidis pathogenesis. Methods in molecular biology (Clifton, N.J.), 1106, 17-31.

Otto, M. (2018). Staphylococcal Biofilms. Microbiology spectrum, 6(4), 10.1128/microbiolspec.GPP3-0023-2018.

Parham, P. (2014). The immune system. Garland Science. Fourth edition, Taylor \& Francis Group, LLC, New York, NY.

Pérez-Velázquez, J., Gölgeli, M., García-Contreras, R. (2016). Mathematical Modelling of Bacterial Quorum Sensing: A Review. Bulletin of mathematical biology, 78(8), 1585-1639. 
Petrova, O.E., Sauer, K. (2016). Escaping the biofilm in more than one way: desorption, detachment or dispersion. Current opinion in microbiology, 30, 67-78.

Cerca, N., Jefferson, K.K., Oliveira, R., Pier, G.B., Azeredo, J. (2006). Comparative antibody-mediated phagocytosis of Staphylococcus epidermidis cells grown in a biofilm or in the planktonic state. Infection and immunity, 74(8), 4849-4855.

Priyanka, S. (2014). Comparison of biofilm production in methicillin resistant Staphylococcus aureus and methicillin sensitive Staphylococcus aureus as a marker of virulence along with their antibiogram in clinical isolates at ESI-PGIMSR, Rajajinagar, Bangalore (Doctoral dissertation).

Pruneau, M. (2008). Étude transcriptomique de Staphylococcus aureus résistant à la méthicilline (SARM) (Doctoral dissertation, Université de Sherbrooke).

Rao, T.S. (2020). Bacterial Biofilms and Implant Infections, A Perspective. Arch Orthop., 1(4), 98-105.

Reddy, L.V., Wee, Y.J., Reddy, L.P.A., Bramhachari, P.V. (2019). Bacterial quorum sensing, challenges and prospects in food microbiology. In implication of quorum sensing and biofilm formation in medicine, agriculture and food industry (pp. 221-249). Springer, Singapore.

Rohde, H., Frankenberger, S., Zähringer, U., Mack, D. (2010). Structure, function and contribution of polysaccharide intercellular adhesin (PIA) to Staphylococcus epidermidis biofilm formation and pathogenesis of biomaterial-associated infections. European Journal of Cell Biology, 89(1), 103-111.

Rowson, C., Townsend, R. (2016). Biofilms, prevention and treatment. British Journal of Hospital Medicine, 77(12), 699-703.

Sabaté Brescó, M., Harris, L.G., Thompson, K., Stanic, B., Morgenstern, M., O'Mahony, L., Richards, R. G., Moriarty, T.F. (2017). Pathogenic Mechanisms and Host Interactions in Staphylococcus epidermidis Device-Related Infection. Frontiers in microbiology, 8, 1401.

Sauer, K., Rickard, A.H., Davies, D.G. (2007). Biofilms and biocomplexity. Microbe-American Society for Microbiology, 2(7), 347.

Sause, W.E., Buckley, P.T., Strohl, W.R., Lynch, A.S., Torres, V.J. (2016). Antibody-Based Biologics and Their Promise to Combat Staphylococcus aureus Infections. Trends in pharmacological sciences, 37(3), 231-241.

Senturk, S., Ulusoy, S., Bosgelmez-Tinaz, G., Yagci, A. (2012). Quorum sensing and virulence of Pseudomonas aeruginosa during urinary tract infections. Journal of infection in developing countries, 6(6), 501-507.

Shahrooei, M., Hira, V., Khodaparast, L., Khodaparast, L., Stijlemans, B., Kucharíková, S., Burghout, P., Hermans, P.W., Van Eldere, J. (2012). Vaccination with SesC decreases Staphylococcus epidermidis biofilm formation. Infection and immunity, 80(10), 3660-3668.

Silva-Santana, G., Castro, H., Ferreira, B.L. Alves, F.A. (2015). Research Paper Staphylococcus aureus Biofilm development: The urgent need for treatment alternatives. Journal of Global Biosciences, 4(5), 2092 2107.

Singh, S., Singh, S.K., Chowdhury, I., Singh, R. (2017). Understanding the Mechanism of Bacterial Biofilms Resistance to Antimicrobial Agents. The open microbiology journal, 11, 53-62.

Skariyachan, S., Sridhar, V.S., Packirisamy, S., Kumargowda, S.T., Challapilli, S.B. (2018). Recent perspectives on the molecular basis of biofilm formation by Pseudomonas aeruginosa and approaches for treatment and biofilm dispersal. Folia microbiologica, 63(4), 413-432.

Skurnik, D., Cywes-Bentley, C., Pier, G.B. (2016). The exceptionally broadbased potential of active and passive vaccination targeting the conserved microbial surface polysaccharide PNAG. Expert review of vaccines, 15(8), 1041-1053.

Smith, M.E. (2016). Endotoxin-induced inflammation in healthy human airways. (Doctoral dissertation University of Gothenburg, Sahlgrenska Academy).
Somerville, G.A., Proctor, R.A. (2009). The Biology of Staphylococci, Kent, B. Crossley, M.D., Kimberly, K., Jefferson, P.H.D., Gordon, L., Archer, M.D., (2009) Staphylococci in Human Disease. Second Edition, P.1-18, Blackwell Publishing Ltd. https://doi.org/10.1002/9781444308464.ch1.

Sparling, B.A. (2013). Total Synthesis of Hyperforin. (Doctoral dissertation) Harvard University. https://dash.harvard.edu/handle/1/11181077.

Speziale, P., Pietrocola, G., Foster, T.J., Geoghegan, J.A. (2014). Proteinbased biofilm matrices in Staphylococci. Frontiers in cellular and infection microbiology, 4, 171.

Subhi, H.T., Abdul, F.R. (2020). Activity of IgA Protease secretion by Proteus vulgaris From Urinary Tract Infection Patients. International Journal of Pharmaceutical Research,12(1), 275-281.

Surewaard, B.G.J. (2013). Immune evasion by Gram-positive pathogens. Utrecht University.

https://dspace.library.uu.nl/bitstream/handle/1874/274524/surewaard.pdf?se quence $=2 \&$ is Allowed $=\mathrm{y}$.

Tam, K., Torres, V.J. (2019). Staphylococcus aureus Secreted Toxins and Extracellular Enzymes. Microbiology spectrum, 7(2),

10.1128/microbiolspec.GPP3-0039-2018

Turkina, M.V., Vikström, E. (2019). Bacteria-Host Crosstalk: Sensing of the Quorum in the Context of Pseudomonas aeruginosa Infections. Journal of innate immunity, 11(3), 263-279.

Van Gestel, J., Vlamakis, H., Kolter, R. (2015). Division of Labor in Biofilms: the Ecology of Cell Differentiation. Microbiology spectrum, 3(2),26.

Van Houdt, R., Michiels, C.W. (2010). Biofilm formation and the food industry, a focus on the bacterial outer surface. Journal of applied microbiology, 109(4), 1117-1131.

Vasudevan, R. (2014). Biofilms, microbial cities of scientific significance. $J$ Microbiol Exp, 1(3), 84-98.

Veerachamy, S., Yarlagadda, T., Manivasagam, G., Yarlagadda, P.K. (2014). Bacterial adherence and biofilm formation on medical implants: a review. Proceedings of the Institution of Mechanical Engineers. Part H, Journal of engineering in medicine, 228(10), 1083-1099.

Verderosa, A.D., Totsika, M., Fairfull-Smith, K.E. (2019). Bacterial Biofilm Eradication Agents: A Current Review. Frontiers in chemistry, 7, 824.

Wh, H., Hatem, M.E., Elnwary, H.A., Sediek, S.H. (2016). Characterization of antimicrobial resistant bacterial pathogens recovered from cases of bovine mastitis with special reference to Staphylococcus aureus. Journal of Veterinary Medical Research, 23(1), 15-25.

Xu, L.C., Siedlecki, C.A. (2014). Bacterial adhesion and interaction with biomaterial surfaces. Biointerfaces, Where Material Meets Biology, (10), 365 .

Zecconi, A., Scali, F. (2013). Staphylococcus aureus virulence factors in evasion from innate immune defenses in human and animal diseases. Immunology letters, 150(1-2), 12-22. 